\title{
Edith Magalhães Fraenkel: The greatest figure of Brazilian Nursing
}

\author{
EDITH DE MAGALHÃES FRAENKEL: O MAIOR VULTO DA ENFERMAGEM BRASILEIRA \\ EDITH DE MAGALHÃES FRAENKEL: LA MAYOR FIGURA DE LA ENFERMERÍA \\ BRASILEÑA
}

\author{
Taka Oguisso $^{1}$, Genival Fernandes de Freitas ${ }^{2}$, Magali Hiromi Takashi ${ }^{3}$
}

\begin{abstract}
The present study aimed to describe and analyze the career of Edith Magalhães Fraenkel and her important legacy to Brazilian nursing. The methodology chosen was a documentary analysis of her areas of participation based on documents of the Historical Cultural Center of Iberian-American School of Nursing of the University of São Paulo (Universidade de São Paulo, USP) and in the Rectory of the same University. The following thematic topics were categorized: preparation for leadership, moving to São Paulo, creation of the School of Nursing of USP, event organization, and unique developments at the end of her career. We conclude that Mrs. Edith Fraenkel is the most important figure of Brazilian nursing, thanks to her immeasurable work as a leader of the profession, nationally and internationally.
\end{abstract}

\section{DESCRIPTORS}

History of nursing

Biography

Societies, Nursing

\section{RESUMO}

Os objetivos do presente estudo foram descrever e analisar a carreira profissional de Edith Magalhães Fraenkel e seu imenso legado à Enfermagem brasileira. A metodologia escolhida foi a análise documental sobre a atuação da personagem, com base em documentos existentes no Centro Histórico Cultural da Enfermagem IberoAmericana da Escola de Enfermagem da Universidade de São Paulo e na Reitoria da mesma Universidade. Os seguintes tópicos temáticos foram categorizados: preparação para liderança, mudança para São Paulo, fundação da Escola de Enfermagem da USP, organização de eventos e a ocorrência de fatos estranhos no final da carreira. Conclui-se que Da. Edith Fraenkel é o maior vulto da Enfermagem brasileira, graças a seu labor incomensurável como líder da profissão, nacional e internacionalmente.

\section{DESCRITORES}

História da enfermagem

Biografia

Sociedades de Enfermagem

\section{RESUMEN}

Los objetivos del presente estudio fueron describir y analizar la carrera profesional de Edith de Magalhães Fraenkel y su enorme legado para la Enfermería brasileña. La metodología escogida fue el análisis documental sobre las actividades desarrolladas por este personaje, basada en documentos existentes en el Centro Histórico-Cultural de la Enfermería Ibero-Americana, de la Escuela de Enfermería de la Universidad de Sao Paulo (USP) y en la Rectoría de la misma Universidad. Los siguientes ejes temáticos fueron categorizados: preparación para el liderazgo; transformaciones para Sao Paulo; fundación de la Escuela de Enfermería de la USP; organización de eventos y la aparición de hechos extraños al final de la carrera. Se concluye que Edith Fraenkel es el personaje más importante de la Enfermería brasileña, gracias a su inconmensurable labor como líder de la profesión, nacional e internacionalmente.

\section{DESCRIPTORES}

Historia de la enfermería

Biografía

Sociedades de Enfermería

${ }^{1}$ Nurse. Professor at the Department of Professional Orientation of the School of Nursing, University of São Paulo. São Paulo, SP, Brazil. takaoguisso@uol. com.br ${ }^{2}$ Nurse. Associate Professor at the Department of Professional Orientation of the School of Nursing, University of São Paulo. São Paulo, SP, Brazil. genivalf@usp.br ${ }^{3}$ Nurse. Master of Science, School of Nursing, University of São Paulo. São Paulo, SP, Brazil. magalitakashi@usp.br 


\section{INTRODUCTION}

Born in the city of Rio de Janeiro on May 9, 1889, the year of the Proclamation of the Republic, Edith de MagaIhães Fraenkel, who became professionally known as Mrs. Edith (Dona Edith), was the daughter of Aldina Botelho de Magalhães and Carlos Fraenkel and the granddaughter of the abolitionist Lieutenant Colonel Benjamin Constant de Botelho Magalhães (1837-1891). From this illustrious Brazilian heritage, she inherited her strength of character, determination, capacity for work, and a deep love for her country, which are attributes that are evident in her intentions and actions and which garnered the respect for her fellow countrymen ${ }^{(1)}$.

Mrs. Edith belonged to a cultured family that was politically and socially prominent, which later favored her social trajectory and opened doors in the profession and in society. Due to her father's diplomatic career, little Edith went to live abroad with her family at two years of age and only returned to Brazil at 17 years of age.

Her childhood was spent in Sweden, Germany, and Uruguay. In these countries, she learned to read and learned the local language, in addition to French, which was the official language in the embassies at the time. She became a polyglot who mastered English, Swedish, German, Italian, Spanish, French, and Portuguese. In 1906, with the death of her father, the family moved permanently to Rio de Janeiro, where they established residence ${ }^{(1)}$.

With the financial difficulties faced after her mother became a widow, Mrs. Edith completed the teacher-training course and taught primary school in a private school in the neighborhood of Santa Thereza. The principal of this school was the sister-in-law of Maurício de Abreu, secretary of the Department of Public Health. Thus, Mrs. Edith found out about the health visitors course of the Brazilian Red Cross. In 1918, she completed the course at the Practical School of Nurses of the Red Cross, which prepared volunteer rescuers to help the wounded in World War I (1914-1918). This knowledge allowed her to act intensively in the Spanish flu epidemic that, in that same year, spread over Rio de Janeiro and was responsible for more than 15,000 deaths. She worked intensely, day and night, over a prolonged period of time ${ }^{(1)}$.

In recognition for her services during the epidemic, the Brazilian Red Cross awarded her the title of honorary member of the institution. Recognized for her work with the community and the Red Cross and for her interest in the country's health problems, in 1919, she was invited by the Secretary of the National Department of Public Health (Departamento Nacional de Saúde Pública - DNSP) to take the Tuberculosis Service Visitors Course. Later, she was hired to work as a health visitor at the DNSP. Her superiors noticed her capacity for work and leadership, and then placed her at the head of the Visitors Service ${ }^{(1)}$.

The beginning of the 1920s was marked by discussions on behalf of the professionalization of health surveillance in Brazil, mainly involving Carlos Chagas and other figures, such as João de Barros Barreto and Jose Paranhos Fontenelle, as well as doctors from the newly created DNSP and other services who were concerned with hygiene and sanitation problems.

In 1919, Chagas had been in the United States on a study trip. He wanted to improve the health conditions in Brazil, so he contacted American personalities and found out about the important role that nurses played in public health and the type of training they should receive. Convinced that the first step should be the creation of courses for the training nurses according to the American or British standards, he requested and received assistance from the Rockefeller Foundation ${ }^{(2)}$.

However, the health policy of the Brazilian State was formulated only in São Paulo, in 1918, with the creation of the Institute of Hygiene, which is currently the School of Public Health of the University of São Paulo, led by Geraldo Horacio de Paula Souza. The health policy followed the guidelines of the Rockefeller Foundation for teaching and research in public health ${ }^{(2)}$.

The dominant historiography indicates that the vicissitudes of the new regime resulted in health reforms, the establishment of public health policies, and the creation of campaigns, leagues, associations, schools, and other institutional spaces, reaffirming that the health issue in Brazil polarized investments during the First Republic (1889-1930) ${ }^{(3)}$.

The establishment of the Republic also evokes one of the great moments in the history of Brazilian public health and represents one of the milestones in the history of nursing in Brazil, known as Parsons Mission (Missão Parsons). This mission involved approximately 20 American nurses coming to Brazil, including Ethel Parsons, who arrived in Brazil in late 1921 with the dual task of directing the newly created Nursing Service of the DNSP and planning and taking the first steps towards the creation of a school of nursing ${ }^{(3)}$.

Ethel met Mrs. Edith, Head of the Nursing Service of the Tuberculosis Prophylaxis Department, and saw an opportunity to realize what was being conceived. Ethel suggested a degree in nursing for Mrs. Edith using a scholarship from the Rockefeller Foundation. Thus, in April 1922, Mrs. Edith, now 33 years old, went to the United States to study at the Philadelphia General Hospital School of Nursing. At this school, Mrs. Edith met Lilian Clayton, who exerted a strong
Edith Magalhães Fraenkel: the greatest figure of brazilian nursing Oguisso T, Freitas GF, Takashi MH 
influence on her career because she presented her with an important concept in American nursing at the time: a profession needs an association and a journal to progress ${ }^{(4)}$.

The present study aims to describe and analyze the career of Edith de Magalhães Fraenkel and her legacy to Brazilian nursing. Thus, we sought to update past data and revive the memory of the trajectory of this pioneer of national nursing as well as to highlight her contributions to the professionalization of nursing in Brazil.

\section{METHOD}

The present is a historical-social study based on the existing literature and official documents of the Rectory of the University of São Paulo, including processes and reports. The theoretical framework used was based on document analysis, which consists of deciphering the contexts, functions, styles, arguments, points of view... ${ }^{(5)}$. According to this author, apud Saint Georges, the document analysis is based on three phases: the internal criticism (close reading of the text, trying to interpret it); the external criticism or criticism of the witness (what will be examined is no longer the message, the text, but the material aspects of the document, i.e., its authenticity); and finally, the criticism of the testimony (to confront the testimony examined with other testimonies independent from the first - triangulation).

\section{RESULTS}

Having graduated as a nurse, Mrs. Edith returned in October 1925 as the first Brazilian to complete the three-year nursing course. Soon after her arrival, she was designated to replace one of the American ${ }^{(a)}$ instructors of the newly created School of Nurses of the National Department of Public Health, currently the Anna Nery School of Nursing (Escola de Enfermagem Anna Nery - EEAN) of the Federal University of Rio de Janeiro.

\section{Preparation for Leadership}

Thus, Mrs. Edith became the first Brazilian to teach nursing ${ }^{(6)}$. She remained in an instructor role until 1927, when EEAN began to select teachers from among the nurses trained in the first class.

From 1925 to 1927, Mrs. Edith played a leading role in the creation of a nurses association, a project that began with the idea of 35 graduates from the first two classes to create an association of former EEAN students, excluding foreign students and Brazilian students who studied abroad.

Due to her training and experience acquired in the United States, Mrs. Edith was convinced that it was crucial that the nurses could count on a professional organization to represent the whole group. Therefore, she suggested

(a) At that time, all instructors at the Nursing School were American. Mrs. Edith substituted for one of them whose residence time had ended the creation of an association that would bring together all Brazilian and foreign nurses, which was also supported by Ethel Parsons and the other American nurses. Thus, the National Association of Registered Nurses was created on August 12, 1926. Mrs. Edith was the first president elected after the end of the administration of the interim board and held this position from 1927 to 1938.

Ethel Parsons had written a detailed report ${ }^{(6)}$ in 1927 on the auspicious progress of nursing in Brazil achieved by the course created by the nurses from Parsons Mission. This was likely the reason why she was invited by the International Council of Nurses (ICN) to represent Brazil in the international congress that would be held in July 1929 in Montreal, Canada. Mrs. Edith and Ethel worked hard to reorganize the Association to meet the requirements for membership, including the addition of the word Brazilian in the title to identify the country of origin ${ }^{(1)}$ of the affiliated entity.

Thus, this Association, currently called the Brazilian Nursing Association (Associação Brasileira de Enfermagem - ABEn), represented by Mrs. Edith, was accepted as a member of the ICN in 1929, becoming the first Latin American organization $^{(b)}$ to be affiliated. In this event, held in Canada, Mrs. Edith met with her former teacher, Lilian Clayton, who reminded her of the importance of having a journal as well as an association. Thus, when she returned to Brazil, she sought Rachel Haddock Lobo, a nurse who studied in France and was the director of EEAN, to accomplish this idea. In May 1932, the first issue of the Annals of Nursing journal was published, and Mrs. Edith was the editor from 1932 to 1938.

In 1927, Mrs. Edith had resumed her work at the National Department of Public Health as the head nurse. She could count on the aid of some peers who were graduates of the first two classes of the Anna Nery School. From head nurse, she became Director of the Division of Public Health Nursing of the DNSP. In 1931, she accepted the position of General Superintendent of the Nursing Service, replacing Ethel Parsons, who had returned to the United States after working for 10 years in Brazil. During the period in which Mrs. Edith remained in the position, from 1931 to 1938 , she chaired or participated in several committees created to study problems related to healthcare or nursing education in Brazil. EEAN was subordinate to the Superintendence of the Nursing Service, which added to her responsibilities regarding nursing education ${ }^{(7)}$.

There are reports that this was one of the toughest periods of her life. The prevention of tuberculosis was one of the most distressing and most difficult problems to solve at the time, initially due to the lack of qualified personnel for public care. Mrs. Edith had to continue to prepare and

\footnotetext{
(b) Chronologically, the Cuban nursing association was accepted as a member in 1925; thus, before ABEn. However, the Cuban organization cut ties with ICN in 1959, after the Revolution, and only became a member again in 1981. Thus, Brazil is considered the first Latin American member of ICN, given that it became a member in 1929 and continued to be affiliated, even though it transferred the membership from $A B E n$ to COFEN in 1997.
} 
use home visitors who performed the work with the needy population of Rio de Janeiro. This population was grouped in hills that were often difficult to access and were always averse to any intrusion in their homes. There was also a lack of nurses to cope with the health problems in the DNSP to establish a direct connection between the Service and the homes of the patients. However, the results of the effort seem to have been very positive, considering the difficulties that had to be overcome or circumvented ${ }^{(7)}$.

In 1939, due to changes in the ministries, Mrs. Edith became Superintendent of the Nursing Service of the Ministry of Education and Health. She was invited to take over the direction of the school of nursing that would be established in São Paulo, linked to the School of Medicine of the University of São Paulo, thanks to an agreement between the Rockefeller Foundation and the government of the state. For this purpose, she was offered a one-anda-half-year stay in the United States and Canada beginning in January 1940 to prepare for the job.

\section{Moving to São Paulo}

The Rockefeller Foundation was willing to contribute financially to build the School of Medicine and to provide equipment for the Institute of Hygiene through an agreement with the Government of the State of São Paulo in 1925. In this agreement, the Foundation stipulated the creation of a school of nursing according to the standards of the EEAN of Rio de Janeiro as a condition for the financial aid.

The Medical School was built and opened in 1931, but the government had not fulfilled its part of the agreement regarding the school of nursing. Therefore, the Rockefeller Foundation sent a nurse, Mary E. Tenant, to press the authorities to fulfill the terms of the agreement signed in 1925. Thus, in 1938, a new agreement was signed and ultimately resulted in the creation of the School of Nursing, based on the latest resources on nursing education available in the United States, as part of the university system ${ }^{(8)}$.

Thus, Mrs. Edith moved to São Paulo and brought along the Brazilian Nursing Association and the Annals of Nursing journal (currently, the Brazilian Journal of Nursing). Soon after her arrival in 1942, Mrs. Edith felt that a state nursing association was necessary, but according to a suggestion from Haydee Guanais Dourado, she decided that it should be a state division of ABEn, which was still called the Brazilian Association of Graduate Nurses (Associação Brasileira de Enfermeiras Diplomadas - ABED). In addition, without a national unity for the profession, the state entity would be excluded from the ICN, which only accepted one organization per country as a member. Thus, on May 25, 1945, the ABEn-São Paulo was created, and Mrs. Edith was elected the first president of the first division of ABEn in Brazil, a position that she kept until 1948.

Mrs. Edith participated in numerous activities, often accumulating positions and roles from colleagues who did not have the time or inclination to complete the tasks, developing a huge set of achievements throughout her professional life.

Tireless, she decided to reactivate the Annals of Nursing journal, whose publication was discontinued in 1941. When she resumed publication in 1954, she took the opportunity to give the journal a new name. The publication was renamed the Brazilian Journal of Nursing but kept the numbering started by Annals of Nursing. Thus, the journal started with the new name from volume XV.

Strength of character, authority, dedication, entrepreneurship, and leadership were qualities of Mrs. Edith that were widely recognized by her peers, such as Amália Corrêa de Carvalho, who said that Mrs. Edith was the greatest figure that the Brazilian nursing ever had ${ }^{(8)}$ and that besides her vast general culture, she was dynamic, efficient, idealistic and altruistic, in short:

(...) a unique, exceptional figure of a born leader, nurse by vocation and conscious choice, feminist by conviction, great administrator, capable of being extremely energetic, authoritarian, and at the same time human and gentle according to the circumstances and to the type of people with whom she dealt $(\ldots)^{(1)}$ and also the pioneer of the pioneers ${ }^{(9)}$.

This title can be safely changed to the greatest figure in Brazilian nursing of all time because, in the professional historiography of Nursing, no other professional has played so many roles and collected so many great achievements. She left a huge legacy for all generations of nurses after her. It is important to note that this was a time when there was still a strong social prejudice against the profession, which made things more difficult. Mrs. Edit knew how to blaze new paths and pave the way for all of the professionals today who can enjoy the prestige and recognition from society that has also been translated into improved economic and wage conditions.

\section{Creation of the School of Nursing}

A The School of Nursing of São Paulo (Escola de Enfermagem de São Paulo - EESP), currently the School of Nursing of the University of São Paulo (Escola de Enfermagem da Universidade de São Paulo - EEUSP), was created by the State Decree-Law No. 13040 on October 31, 1942 and was equated by the Federal Decree No. 21965 on October $21,1946^{(10)}$. The assent to this equivalence had been recorded by the nurse Rosaly Taborda, designated by the Ministry of Education and Health for this verification, by indication of the EEAN. Thus, under Federal Decree No. 20109 on June 15, 1931, which regulated the practice of nursing in Brazil and established the conditions for equivalence of the schools of nursing (in effect at the time), the School of Nursing of USP had to be initially equated.

The first class consisted of 38 students, and 32 were teachers from the teacher-training school commissioned by the Government of the State. The course was held in 1,095 effective days, with 44 hours per week of activities
Edith Magalhães Fraenkel: the greatest figure of brazilian nursing

Oguisso T, Freitas GF, Takashi MH 
and 70 days of vacation in the three years, which corresponded to 34 months of effective teaching performed by just three teachers: Haydée Dourado, Maria Rosa S. Pinheiro, and Ruth Borges Teixeira(8). However, Mrs. Edith had the collaboration of an American nurse, Miss Ella Hasenjaeger, from the Institute of Inter-American Affairs (Instituto de Assuntos Inter-Americanos - IAIA), Master of Nursing by the Teachers' College of Columbia University. Hasenjaeger came to act as a consultant in the School, from 1944 to 1951, but given the lack of teachers, she also took on teaching activities ${ }^{(8)}$. Her efforts introduced the teaching of psychiatric nursing in the curriculum of the School, unprecedented at the time, which was subsequently followed by all schools and eventually included in the core curriculum of nursing.

In 1949, the first federal law regulating nursing education in Brazil was enacted, Law No. 775 on August 6, 1949, which defined two basic levels for nursing education: the nursing program, with 36 months; and the nursing assistant course, to be completed within 18 months. From this law, schools of nursing became more recognized, and the equation was not necessary for them to function any longer $^{(10)}$. When regulated by Decree 27426 on November 14, 1949 , this Law also created the congregation figure in article 40-42, making it possible to separate the School of Nursing from the School of Medicine. However, the separation process occurred in fact subsequent to Decree 42809 on December 20,1963, which transformed the School of Nursing of São Paulo in a higher education institution named the School of Nursing of USP. The adaptation of the Regulation of the School to this law took a long time; only in 1954 was the new regulation approved, issued by State Decree No. 23796C from November 10, 1954 ${ }^{(10)}$.

In the 1940s, Brazilian nursing needed leaders in all regions of Brazil. In parallel, World War II imposed a necessary and urgent multiplication of the profession. Not superimposing the previously required quality, after 1930, professional training was significantly expanded through the pedagogical principle of the Rockefeller Foundation, whose demonstration effect had resulted in an effective contingent of scholars who maintained their studies funded by the Public Health Special Service (Serviço Especial de Saúde Pública - SESP). As proposed by the Rockefeller Foundation, the health facilities were resized to form a new group of elite professionals ${ }^{(3)}$.

The national population of nurses should be composed of women and men capable of promoting the health of the population without restriction and consolidating official assistance institutions, expanding the meaning attributed to the relationship between health and disease. The teaching assumed a fundamental importance becau

se teaching could resize the professional practice and create new fields. At the core of the social changes, nursing education was reconfigured, as was the professional profile of its contingent.
From November 1941, Mrs. Edith began the organization and preparation of the Nursing Service of the Teaching Hospital (Hospital das Clínicas - HC), which was in the final stages of construction and where the School would be installed. In the beginning, she was director of the School and advisor of the Nursing Subdivision of the Hospital. In this position, aided by nurses hired after August 1942, both for the hospital and for the School, she wrote nursing procedures and techniques to be used by the hospital staff and the teachers and students of the School(8).

She was nominated as Secretary of the Committee created to study the building plans of the building intended to house the head office of the School and the boarding school for the students. This time was a period of intense work, divided between the organization and the establishment of the nursing service of the $\mathrm{HC}$ and the planning of all the initial activities of the School, including the accommodations for the students because the boarding system was compulsory at the time ${ }^{(8)}$.

Concerned with the health of the students, given the intensity of the studies and work in several departments of the HC, Mrs. Edith kept an outpatient clinic and a small infirmary, known as the Health Room, to treat students who had minor health problems. The nursing care was provided by the students under the supervision of one of the teachers from the School. In addition to this supervision, the Health Room received a daily visit from a doctor, who also taught the General Pathology course. This outpatient care was extended to all servers of the School ${ }^{(1)}$. The extinction of the boarding system in EEUSP, in 1973, made the Health Room unnecessary.

Until their own building was finished, the school was installed inside the Teaching Hospital, which was also beginning its service and still lacked equipment and personnel. Finally, the EEUSP building was inaugurated on October $31,1947^{(1)}$.

\section{Event organization}

Mrs. Edith believed that the progress of the profession in Brazil would be slow and difficult if the efforts of all nurses were not combined to promote its development by all means within their reach. Therefore, she believed that this job could be easier if it were developed by the ABEn as the unifying organ of the nursing class $^{(4)}$.

The events that preceded the organization of conferences, as well as those that developed when each conference was being held, demonstrated that there was acertain uniformity of planning and execution, respecting the differences of the time in which they occurred ${ }^{(4)}$.

At the monthly ABEn meeting held on June 12, 1945, the president Zaíra Cintra Vidal informed the associates that she had received a proposal from the Nurses School of the São Paulo Hospital (currently UNIFESP) for the $A B E D$ to conduct a national nursing congress. The São 
Paulo division of the ABEn decided to take over and conduct the First National Nursing Congress in July 1947 in the auditorium of the School of Nursing of USP, whose building was almost finished and could host all of the participants coming from the different states of the country. The idea of holding the conference came from Mother Marie Domineuc, a French nun and one of the founders of that School. Because she formed such a small group, having a unit of the National Association that would promote the evolution seemed essential to $\operatorname{her}^{(8)}$.

This event was entirely planned, organized, directed, and coordinated by Mrs. Edith and a small group of nurses and teachers of EEUSP. Because it was the first event and had a thorough programming, the conference was a great success and prompted all of the annual meetings to discuss the problems of the profession, the professionals, the schools of nursing and nursing assistants, and the proper referral of the issues to the competent agencies ${ }^{(4)}$. This event became a tradition among nursing professionals and up to the present day, in 2012, it is in its $64^{\text {th }}$ incarnation. Its name was changed only in 1956, when it was held in Porto Alegre and became the Brazilian Congress of Nursing, keeping, however, the numerical order of the event (IX).

This first conference was a milestone that effectively initiated the successive debates and discussions for the reformulation of the teaching and practice of nursing in Brazil. It is worth noting that the first three conferences had the American nurse Ella Hasenjaeger as president of the Executive Committee ${ }^{(4,11)}$. For ABEn, such events still constitute

one of the most important accomplishments as a source of inspiration for the development of the profession and of nurses as useful citizens to society ${ }^{(4)}$.

There is no doubt that the unquestionable leadership of Mrs. Edith took the first steps toward the union of nurses around the multiple problems that were studied together to achieve satisfactory results for everyone, from Rio Grande do Sul to the Amazonas ${ }^{(1,7,9)}$.

Numerous state and federal authorities were present at the opening session of the First National Congress of Nursing held in EEUSP in 1947, including the governor of the State, Ademar de Barros, the dean of the University of São Paulo, Benedito Montenegro, and the director of the National Department of Health. In her brief greeting to the participants and guests, as president of the São Paulo division of ABEn, Mrs. Edith directly and objectively focused on some basic principles for nursing education:

(...) The analysis of the current status of nursing in Brazil demonstrates two fundamental facts: first, the disparity between the number of registered nurses and the number that is necessary for good nursing; and secondly, the danger that the trend to fill this gap, allowing the rapid and incomplete formation of nurses, may represent, either morally or professionally. Haste is the enemy of perfection.
This Congress aims to address exactly these two points: there is a need to foster the vocation to increase the number of professionals, but appropriate technical preparation is also necessary, as well as keeping this preparation updated ${ }^{(1)}$.

To conclude the greeting, she reminded all participants that the union of the nurses is the main factor in the development of the profession.

Among the seven resolutions approved at the First National Congress of Nursing, three can be highlighted because they had many repercussions and demanded significant: 1) resume the work aimed at creating a board of nursing, a subject that was already being discussed and that since 1944 constituted an important item of the work plans of the board of the Association and of the initiatives of the nurses with the relevant authorities; 2) send an invitation to the ICN to hold the $X$ International Congress in Brazil; 3) add a minimum two-month internship in a mental illness hospital to the theoretical psychiatry teaching at the Schools of Nursing, given the lack of preparation of nurses in the psychiatry field and its importance in the medical field ${ }^{(1,7)}$.

To celebrate this first event of Brazilian nurses and to honor the guests from São Paulo, the poet Guilherme de Almeida was asked to write a poem dedicated to them. Thus, the class was toasted with the poem The hand that never fails, published in the April-June 1947 edition of the Annals of Nursing(1).

The first resolution was completed more than 20 years later with the creation of the Federal Council of Nursing (Conselho Federal de Enfermagem - COFEN) in 1973. In 1953, the X International Congress of Nursing was held in Brazil, sponsored by ICN. This congress was the first event of this organization in a country from the southern hemisphere and in a Latin American country, and the teaching of theoretical and practical psychiatric nursing became part of the core nursing curriculum.

Therefore, the Congress of Nursing of 1947 consolidated the paradigm shift within Brazilian nursing and provided the diffusion of the new professional profile. Thus, to recover the historical memory of the first scientific event of Brazilian nursing implies not only reevaluating the paths taken by the art and science of care but noticing interfaces between the past, present, and future of Brazilian nursing.

\section{DISCUSSION}

Despite all dedication to the class and the monumental work done, unfortunately, Mrs. Edith, still in the role of director of EEUSP, was the target of whistleblowing. The chairman of the inquiry, Professor Gabriel Sylvestre Teixeira de Carvalho, from the School of Veterinary Medicine of USP (Faculdade de Medicina Veterinária da USP), requested the removal of Mrs. Edith and Mrs. Anita Maria Valver- 
de, manager of the boarding school, on July 16, 1955; the first because of the authority of the role and the second because, supposedly, she could interfere in the determination of facts (USP Process No. 55.1.10814.1.5 of 7/28/1955, which addresses the removal of Professor Edith de MagaIhães Fraenkel from the position of director of the School of Nursing). During this 30-day preventive suspension period, neither woman could stay within the School.

To replace Mrs. Edith, the nurse Clarice Della Torre Ferrarini, who worked at the $\mathrm{HC}$ of the School of Medicine of USP, was appointed (USP Process No. 55.1.10427.1.1 of $7 / 25 / 1955$, for the indication of Nurse Clarice Della Torre Ferrarini as a substitute for Edith de Magalhães Fraenkel). However, this substitution was revoked on August 12,1955 , when the preventive suspension was lifted, less than a month from the start of the inquiry. The harm, however, had already been caused; the humiliation, the violence of the suspension, the injustice, and the requirement to remain outside the School, with no regard to the work she had developed. Sister Maria Tereza Notarnicola, Daughter of the Charity of Saint Vincent de Paul, a longtime friend, was in charge of helping Mrs. Edith pack her belongings and move quickly to Rio de Janeiro in an extremely short time of 24 hours.

Even after being rehabilitated with the lifting of the suspension, Mrs. Edith decided not to return to São Paulo, choosing to stay in Rio de Janeiro and file a retirement application because she had worked enough time to retire (USP Process No. 55.1.11769.1.3, of 9/22/1955, which addresses the retirement of Edith de Magalhães Fraenkel). She had started to work in February 1921 as a health visitor. Then, she worked as head nurse and general superintendent in the former Ministry of Education and Health and then commissioned for the School of Nursing until she was named director of the School of Nursing in January 1943 . She had worked for 31 years, one month, and 28 days. At the time, she retired with a salary of $\mathrm{Cr} \$ 13,200$, which represented in $2012 \mathrm{R} \$ 1,677.52$, slightly more than twice the minimum wage, for a director of the EEUSP.

\section{REFERENCES}

1. Carvalho AC. Edith de Magalhães Fraenkel. São Paulo: EEUSP; 1992.

2. Castro Santos LA, Faria L. Saúde e história. São Paulo: Hucitec; 2009.

3. Souza Campos PF, Oguisso T. A Escola de Enfermagem da Universidade de São Paulo e a reconfiguração da identidade profissional da enfermagem brasileira. Rev Bras Enferm. 2008;61(6):892-8.

4. Carvalho AC. Associação Brasileira de Enfermagem: documentário, 1926-1976. Brasília: ABEn; 1976.
ABEn helped with legal assistance but also lacked funds for helping more effectively. One of her former students, Lydia da Dores Matta, director of the Alfredo Pinto School of Nursing at the time (which currently belongs to the Federal University of the State of Rio de Janeiro - Unirio) hired Mrs. Edith to work as a consultant for a period of time.

Thus, Mrs. Edith, the greatest figure of Brazilian Nursing of all time, died silenced, poor, lonely, and forgotten by many, on April 5, 1969, at 79 years of age on a Holy Saturday in the city of Rio de Janeiro.

\section{CONCLUSION}

For the large and innovative work developed and the great legacy she left for all generations of nurses, Mrs. Edith de Magalhães Fraenkel has merited the publication of several biographies in national journals, including a book, and the granting of awards in her name. However, she deserves much more than words written in journals that may soon be forgotten and that do not have the symbolic strength of something more solid and consistent.

In her memory as a professional, undisputed leader, visionary, reformer, and great entrepreneur and also in reparation for the injustice she suffered, Mrs. Edith deserves at least a bronze bust in the courtyard or in front of the School of Nursing of USP, which she created, organized, and directed. A mere photograph in the hallway next to the other directors could not do justice to the immeasurable work that transformed EEUSP in a watershed event.

The strength of her work propelled EEUSP to a national leading position ahead of its time in training professionals qualified for the practice, teaching, research, and management of nursing and health services. With the innovations implemented by Mrs. Edith and continued by her successors (from Mrs. Maria Rosa S. Pinheiro), EEUSP can make significant differences and contribute with the most progressive innovations, creating models and challenging traditions.
5. Silva OC. Pesquisa documental. In: Oguisso, Souza Campos PF, Freitas GF. Pesquisa em história da enfermagem. São Paulo: Manole; 2011. p. 339-62.

6. Parsons E. Modern nursing in Brazil. Geneva: The International Council of Nurses; 1927.

7. Mancia JR, Padilha MICS. Trajetória de Edith Magalhães Fraenkel. Rev Bras Enferm. 2006;59(n.esp):432-7.

8. Carvalho AC. Escola de Enfermagem da USP: resumo histórico, 1942-1980. Rev Esc Enferm USP. 1980;14 Supl:1-275. 
9. Secaf V, Costa HCBV. Enfermeiras do Brasil: história das pioneiras. São Paulo: Martinari; 2007.

10. Pinheiro MR. Histórico da Escola de Enfermagem da Universidade de São Paulo. Rev Esc Enferm USP. 1967;1(1):3-34.
11. Santos TCF, Barreira IA, Fonte AS, Oliveira AB. American participation in the creation of a nurse model in Brazilian society in the 1920's. Rev Esc Enferm USP [Internet]. 2011 [cited 2012 May 15];45(4):966-73. Available from: http://www. scielo.br/pdf/reeusp/v45n4/en_v45n4a25.pdf 